\title{
Verticillate Cladonia species (Lichenized Ascomycota) from high-altitude environments of Serra do Mar in Southern Brazil
}

\author{
Ana Marcia Charnei ${ }^{1,2}$ and Sionara Eliasaro ${ }^{1}$
}

Received: 23.11.2012; accepted: 30.01.2013

\begin{abstract}
Verticillate Cladonia species (Lichenized Ascomycota) from high-altitude environments of Serra do Mar in Southern Brazil). In a survey of the species of Cladonia occurring in high-altitude environments of Serra do Mar in Southern Brazil, eight species with verticillate podetia were found. Cladonia clathrata and C. imperialis are new records for the Southern Brazil; C. Alagellaris, C. penicillata, and C. verticillaris are new for the State of Santa Catarina; C. calycanthoides and $C$. rappii are new for the State of Paraná. Detailed descriptions, an identification key, illustrations, and taxonomical remarks are provided.
\end{abstract}

Key words: biodiversity, lichenized fungi, Paraná State, Santa Catarina State

RESUMO - (Espécies verticiladas de Cladonia (Ascomycota liquenizados) em ambientes de altitude da Serra do Mar no Sul do Brasil). No levantamento das espécies de Cladonia ocorrentes em ambientes de altitude da Serra do Mar no Sul do Brasil, foram encontradas oito espécies com podécio verticilado. Cladonia clathrata e $C$. imperialis são novas citações para a região Sul do Brasil; C. flagellaris, C. penicillata e C. verticillaris são novas para o Estado de Santa Catarina; $C$. calycanthoides e C. rappii são novas para o Estado do Paraná. São fornecidas descrições detalhadas, chave de identificação, ilustrações e comentários taxonômicos.

Palavras-chave: biodiversidade, fungos liquenizados, Paraná, Santa Catarina

\section{Introduction}

The genus Cladonia P. Browne is very abundant and diverse in environments above $900 \mathrm{~m}$ of altitude on Serra do Mar in Southern Brazil, but is still poor studied. Although 51 species are known for the Paraná and Santa Catarina States (Ahti \& Marcelli 1995, Ahti 2000, Gumboski \& Eliasaro 2011a, b, Gumboski \& Eliasaro 2012a, b), these records are mostly for species occurring in coastal areas and plateaus of the interior of these States. Concerning to species in high-altitude environments of the Serra do Mar in Southern Brazil (above $900 \mathrm{~m}$ of altitude) the only reference is Ahti (2000) who recorded C. cerathophylla (Sw.) Spreng., C. crispatula (Nyl.) Ahti, C. furfuracea Vain. and C. penicillata (Vain.) Ahti \& Marcelli, for the Paraná State.

This study focuses on a group of Cladonia species, formerly treated as Cladonia verticillaris complex, that have podetia with repeatedly centrally proliferating scyphi. This group of species was studied by Ahti \& Marcelli (1995) who recognized eleven taxa, all of them confined to South America.

\section{Materials and methods}

The Serra do Mar extends for about 1,000 km from Rio de Janeiro to Santa Catarina States (Santos 2004). On Paraná State, it comprises a chain of mountains with peaks higher than $1,800 \mathrm{~m}$ of altitude and in the Northern of Santa Catarina State, it ceases to exist as a unit orographic and is in parallel strands of mountains and isolated hills (Almeida \& Carneiro 1998). The lower regions of the Serra do Mar are characterized by humid subtropical climate (Cfa) under the Köppen Climate Classification with hot summers and in the higher parts, by super humid subtropical climate $(\mathrm{Cfb}$ of Köppen), with mild summers and lower thermal averages (Blum et al. 2011, IAPAR 2012). The Serra do Mar is covered by dense rain forest formations

1. Universidade Federal do Paraná, Departamento de Botânica, Laboratório de Liquenologia, Caixa Postal 19031, 81531-970 Curitiba, PR, Brasil

2. Corresponding author: acharnei@yahoo.com.br 
(Floresta Ombrófila Densa), classified as Montana (between 400-1,000 meters) and High-Montana (above 1,000 m) (IBGE 1992). In the uppermost parts, the rainforest is replaced by high-altitude grasslands which are composed primarily by grasses and isolated shrubs.

The field studies were conducted in several hills and mountains of the Serra do Mar on Paraná and Santa Catarina States between $25^{\circ} 03^{\prime}-27^{\circ} 49^{\prime} \mathrm{S}$ and $48^{\circ} 32^{\prime}-49^{\circ} 03^{\prime} \mathrm{W}$, on environments ranging from 900 to $1,887 \mathrm{~m}$ (figure 1), including the highest mountains of Southern Brazil Pico do Paraná $(1,887 \mathrm{~m})$ and Morro Caratuva $(1,850 \mathrm{~m})$. The specimens were collected according to Brodo et al. (2001) and were studied under dissecting and light microscopes using standard microscopic techniques. Lichen substances were determined by spot tests, UV light (Taylor 1967, 1968) and thin layer chromatography (TLC) in solvent C (toluene, glacial acetic acid 10:1) (Culberson \& Ammann 1979, Elix \& Ernst-Russell 1993). Voucher specimens are deposited in the Herbarium of
Universidade Federal do Paraná (UPCB). Additional preserved specimens in MBM are also studied.

\section{Results and discussion}

The verticillate Cladonia is represented in high-altitude environments on the Serra do Mar on Southern Brazil by eight species. The distribution of C. imperialis Ahti \& Marcelli, formerly considered endemic to Serra da Mantiqueira on the Minas Gerais, Rio de Janeiro and São Paulo States (Ahti \& Marcelli 1995, Ahti 2000), here is extended to Southern Brazil. The distribution of $C$. clathrata Ahti \& Xavier Filho is also extended to Southern Brazil. Cladonia flagellaris Ahti \& Marcelli, C. penicillata and C. verticillaris (Raddi) Fr. are the first report for Santa Catarina State and C. calycanthoides (Vain.) Ahti \& Marcelli and C. rappii A. Evans to Paraná State.

Cladonia calycanthoides, C. clathrata and C. fissidens Ahti \& Marcelli are the rarest species in the study area, while C. rappii and C. verticillaris are the most common in both Paraná and Santa Catarina States.

Key to the species of verticillate Cladonia from high-altitude environments in the Serra do Mar on Southern Brazil

1. Scyphi tightly perforated to completely clathrate in basal scyphi 2. C. clathrata

1. Scyphi imperforate to variably perforated but not clathrate

2. Scyphi with toothed margins, imperforate 7. C. rappii

2. Scyphi with laciniated margins, perforated

3. Podetia with melanotic base

4. Surface of podetia smooth, without pruine 5. C. imperialis

4. Surface of podetia arachnoid, with pruine 4. C. flagellaris

3. Podetia without melanotic base

5. Scyphal margins with tuft of black and squarrose rhizines (penicillate) 6. C. penicillata

5. Scyphal margins not penicillate

6. Podetia up to $3.6 \mathrm{~cm}$ tall and forming up to 4 tiers scyphi 3. C. fissidens

6. Podetia $5-20 \mathrm{~cm}$ tall and forming 6-10 tiers scyphi

7. Scyphi $0.3-0.9 \mathrm{~cm}$ wide, pruinose when young 1. C. calycanthoides

7. Scyphi mainly $1.1-2.0 \mathrm{~cm}$ wide, never pruinose 8. C. verticillaris

1. Cladonia calycanthoides (Vain.) Ahti \& Marcelli, Biblioth. Lichenol. 58: 9, 1995. Type: BRAZIL. Minas Gerais: Caraça, 1885, Vainio s.n. (lectotype designated by Ahti \& Marcelli, 1995, TURV 18342).

Figure 2

Primary thallus not seen. Podetia 5.0-7.0 cm tall, 0.5-1.2 mm thick, whitish-grey to greenish-grey, not melanotic at base, usually simple to rarely with two or three proliferations from scyphal center; podetial surface corticate, smooth to slightly verrucose, maculate, slightly glossy, basal regions often cracked to seldom smooth, soredia, granules and squamules absent; scyphi forming 6-8 tiers, which are $0.3-0.9 \mathrm{~cm}$ wide, with internodes $0.4-1.3 \mathrm{~cm}$, pruine only on apical scyphi; scyphal margins laciniate, laciniae frequently branched 1-2 times, rarely 3 times, flattened near scyphal margins to cylindrical at the extremities, mainly erhizinate or with sparse inconspicuous rhizines with up to $0.4 \mathrm{~mm}$ long; upper side of scyphal plates corticate, perforated, brown; lower surface of scyphal plates almost completely corticate, whitish-grey to 


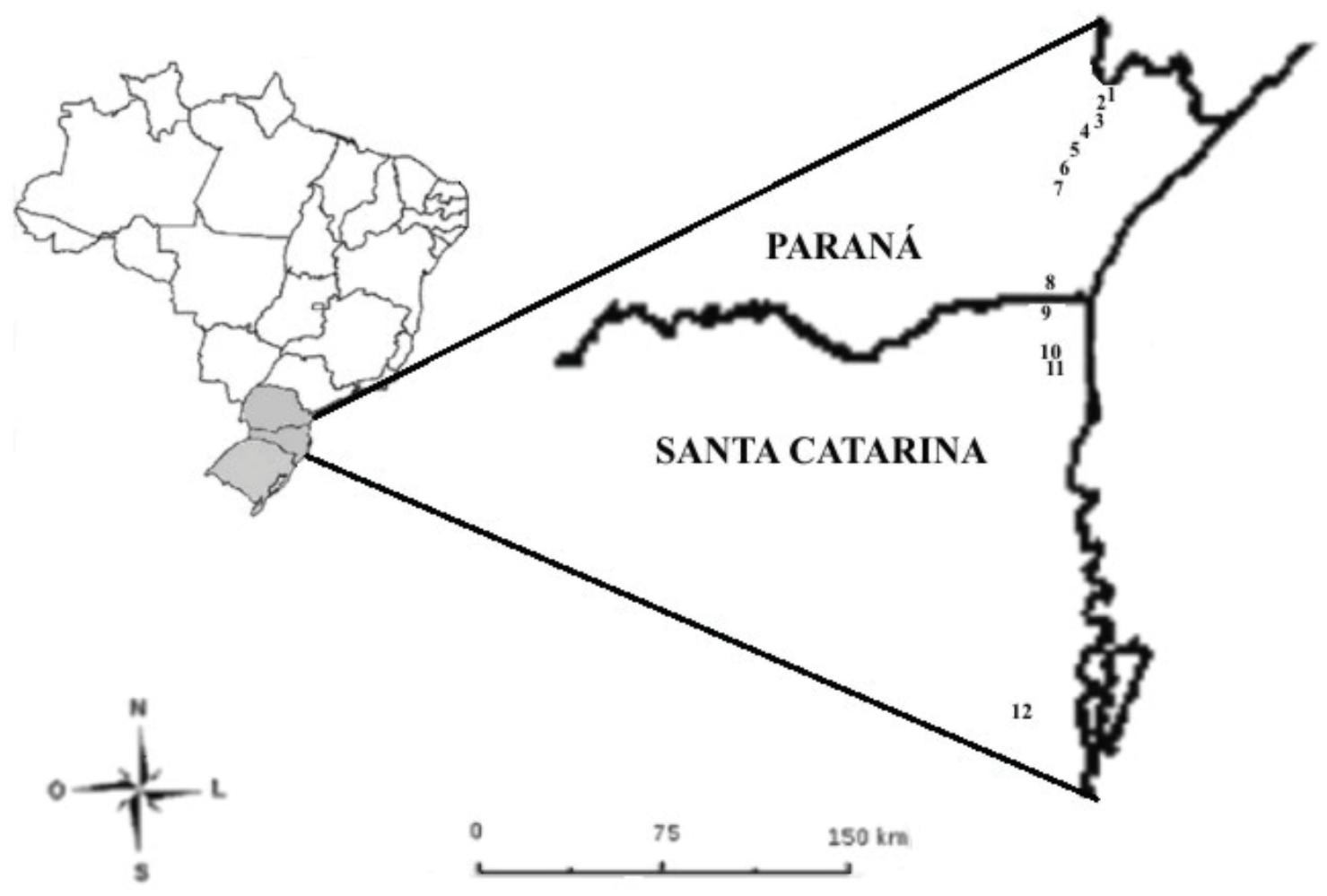

Figure 1: Location of the mountains studied in Serra do Mar. State of Paraná: 1. Serra Virgem Maria; 2. Serra do Capivari; 3. Serra do Ibitiraquire; 4. Serra da Bocaina; 5. Serra da Graciosa; 6. Serra da Baitaca; 7. Serra Marumbi; 8. Serra do Araçatuba. State of Santa Catarina: 9. Serra do Quiriri; 10. Serra Dona Francisca; 11. Serra Queimada; 12. Serra do Tabuleiro.

greenish-grey, not veined; cortex 15-25 $\mu \mathrm{m}$ thick; medulla 150-180 $\mu \mathrm{m}$ thick; stereome 80-130 $\mu \mathrm{m}$ thick, hyaline to yellowish, poorly delimited from medulla; surface of central canal slightly papillated and grooved; hymenial discs at tips of laciniae, brown, imature; ascospores absent; conidiomata uncommon, brown, pyriform, slime hyaline; conidia slightly curved to falciform, 6-9 $\times 1 \mu \mathrm{m}$.

Chemistry: K-, C-, KC-, UV-. TLC: Fumarprotocetraric acid.

This species is characterized by the small scyphi, 0.3-0.9 $\mathrm{cm}$ wide, with laciniate margins, pruinose when young and by the surface of podetia maculate (Ahti \& Marcelli 1995). The shape and size of conidia are described for the first time for this species.

Cladonia verticillaris is a similar species but has scyphi with larger diameter, mainly 1.1-2.0 cm, and does not produce pruine. Cladonia dissecta Ahti is also similar in having pruine at the apical regions and has the size of the podetia and the number and width of the scyphi similar. However, $C$. dissecta has strongly laciniate scyphi and longitudinal fissures and perforations on the surfaces of podetia. It also differs chemically by the occasional production of atranorin (Ahti 2000).

Cladonia penicillata also resembles $C$. calycanthoides but has dense black squarrose rhizines, up $3.0 \mathrm{~mm}$ long, around the scyphal margins.

It is rare in study area, where was found only one specimen on thin layer of sediments on rock.

Distribution: Brazil, in Serra da Mantiqueira and Serra do Espinhaço in the Minas Gerais State (Vainio 1894 - as C. verticillaris f. calycanthoides Vain.) and in Serra Geral, Rio Grande do Sul State (Ahti 2000). It is reported here for the first time from Paraná State.

Specimens examined: BRAZIL. PARANÁ: Campina Grande do Sul, Serra do Ibitiraquire, Morro Tucum, 1,736 m, 16-V-2006, E. Barbosa \& E. Marinero 1413 (MBM). 
2. Cladonia clathrata Ahti \& Xavier Filho in Ahti et al., Trop. Bryol. 7:58, 1993. Type: BRAZIL. Paraíba: Alhandra, $120 \mathrm{~m}$ of altitude, 1987, Ahti \& Xavier Filho 45697 (holotype JPB; isotypes B, $\mathrm{H}, \mathrm{NY}, \mathrm{SP})$.

Figure 3

Primary thallus not seen. Podetia 5.0-12.0 cm tall, 0.1-0.2 cm thick, whitish-green, not melanotic at base, however slightly brownish, frequently simple to rarely with two proliferations from scyphal center; podetial surface corticate, smooth; soredia, granules, squamules and pruine absent; scyphi forming 8-10 tiers, with $0.8-1.0 \mathrm{~cm}$ wide, internodes $1.2-1.8 \mathrm{~cm}$, scyphal margins toothed, teeth whitish, usually simple to seldom dichotomously branched, cylindrical, hollows, erhizinate; upper side of scyphal plates corticate, perforated, completely clathrate in basal scyphi; lower surface of scyphal plates corticate, not veined; cortex 15-25 $\mu \mathrm{m}$ thick; medulla 160-200 $\mu \mathrm{m}$ thick; stereome 120-150 $\mu$ m thick, well delimited from medulla, hyaline to yellowish; surface of central canal papillated; hymenial discs and conidiomata absent.

Chemistry: K-, C-, KC-, UV-. TLC: Fumarprotocetraric acid and traces of physodalic acid.

Cladonia clathrata is characterized by having numerous perforations on the scyphal plates, making the plates clathrate with age, which makes it easily differentiated from all other species of this group.

In the exemplar studied, the podetia are longer than was reported by Ahti et al. (1993) in the original descriptions (2-4.5 cm tall). M.P. Marcelli (personal communication) also observed specimens of $C$. clathrata from Serra do Itatiaia with longer podetia. As the species is known from few specimens the variation in the size of the podetia is not yet established, and it is possible that the development of podetia could be influenced by altitude, as observed in C. imperialis (see under this species).

The single specimen occurring in the study area has the podetial surface smooth, not felty as described by Ahti et al. (1993), however all other morphological characters are according to the original description.

The only specimen found was growing among mosses on rock shade place.

Distribution: Brazil, primarily in Northeast Brazil, particularly on sandy habitats near the coast, Bahia, Paraíba, Pernambuco and Sergipe States, with extensions to Espírito Santo and Minas Gerais States (Ahti et al. 1993) and São Paulo State (Ahti 2000). It is reported here for the first time to Paraná State.
Specimens examined: BRAZIL. Paraná: Campina Grande do Sul, Serra do Ibitiraquire, Morro Caratuva, $25^{\circ} 24^{\prime} \mathrm{S}$ and $48^{\circ} 49^{\prime} \mathrm{W}, 1,850 \mathrm{~m}$ of altitude, 6-VII-2011, A.M. Charnei et al. 171 (UPCB).

3. Cladonia fissidens Ahti \& Marcelli in Ahti et al. Biblioth. Lichenol., 55, 1995. Type: BRAZIL. MinAS Gerais : Caeté, Serra da Piedade, 1,330 m of altitude, 1990, Marcelli, Nash \& Gries 8935 (holotype $\mathrm{H}$; isotype $\mathrm{H}$ ).

Figure 4

Primary thallus persistent to evanescent, consisting of lobed to laciniate squamules, with up to $3.8 \times 4.0 \mathrm{~mm}$, margins smooth, without rhizines, soredia and granules absent; upper surface green to brown, corticate; lower surface white, ecorticate, not veined; cortex 60-85 $\mu \mathrm{m}$ thick; medulla $60-120 \mu \mathrm{m}$ thick; conidiomata absent. Podetia $1.3-3.6 \mathrm{~cm}$ tall, 0.4-0.8 mm thick, brownish, not melanotic at base, usually branched, with up to four branched from scyphal center; podetial surface corticate, smooth, soredia, granules and pruine absent; scyphi forming 1-4 tiers, which are 0.15-0.6 cm wide, internodes 0.4-0.9 cm; scyphal margins strongly laciniate, with squamules normally absent to scarce up to $0.4 \mathrm{~mm}$ long, laciniae terete, always dichotomously branched 1-3 times, recurved, hollows, erhizinate; upper side of scyphal plates corticate, perforated, brown; lower side of scyphal plates corticate, greyish, not veined; cortex 10-20 $\mu \mathrm{m}$ thick; medulla 100-120 $\mu \mathrm{m}$ thick; stereome 55-75 $\mu \mathrm{m}$ thick, well delimited from medulla, hyaline to yellowish; surface of central canal smooth; hymenial discs absent; conidiomata scarce, on short pedicels in scyphal margins, globose to dolioliform, brown, slime absent; conidia absent.

Chemistry: K-, C-, KC-, UV-. TLC: Fumarprotocetraric acid and traces of physodalic acid.

Cladonia fissidens is easily recognized by the small, $1.3-3.6 \mathrm{~cm}$, brown podetia and only specimens of $C$. verticillaris with underdeveloped podetia could be confused with this species. However, in C. verticillaris the scyphi are wider (up to $2.0 \mathrm{~cm}$ ) and the scyphal margins have abundant squamules, while in $C$. fissidens the scyphi are $0.15-0.6 \mathrm{~cm}$ wide and the scyphal margins normally have no squamules.

It is a rare species in the study area, where was found only one specimen growing among mosses on rock in exposed place, isolated from other species of the genus. 




Figures 2-7: 2. Cladonia calycanthoides (E. Barbosa \& E. Marinero 1413). 3. C. clathrata (A. M. Charnei et al. 171). 4. C. fissidens (A. M. Charnei et al. 131). 5. C. flagellaris (A. M. Charnei et al. 314). 6. C. imperialis (A. M. Charnei et al. 211). 7. C. penicillata (P.B. Schwartsburd 1239). Scale bars $=1 \mathrm{~cm}$. 
Distribution: Brazil, along Serra da Mantiqueira and Serra do Espinhaço in the Minas Gerais and Rio de Janeiro States and Serra do Mar, in the Paraná State (Ahti 2000).

Specimens examined: BRAZIL. ParanÁ: Campina Grande do Sul, Serra do Ibitiraquire, Morro do Getúlio, $25^{\circ} 14^{\prime} \mathrm{S}$ and $48^{\circ} 50^{\prime} \mathrm{W}, 1,230 \mathrm{~m}$ of altitude, 6-VII-2011, A.M. Charnei et al. 131 (UPCB).

4. Cladonia flagellaris Ahti \& Marcelli, Biblioth. Lichenol. 58: 18, 1995. Type: BRAZIL. São PAUlo: Peruíbe, ReservaEcológica Juréia-Itatins, Marcelli \& Yano 23721 (holotype, SP; isotype, H). Figure 5

Primary thallus not seen. Podetia $3.0-10.0 \mathrm{~cm}$ tall, 0.4-2.0 mm thick, whitish-grey, strongly melanotic at base, usually simple to seldom with two proliferations from scyphal center; podetial surface corticate, areolate, arachnoid, soredia and granules absent, slightly pruinose; scyphi 4-11 tiers, with 0.4-1.1 mm wide, internodes 0.6-1.7 cm; scyphal margins usually with squamules up to $0.7 \mathrm{~mm}$ long, always strongly laciniated, sometimes totally laciniated, laciniae always dichotomously branched 2-4 times, flattened at the base, cylindrical at the apex, hollows, recurved, extremities darkened and erhizinate; upper side of scyphal plates areolate, perforated, mainly at the basal scyphi; lower side of scyphal plates areolate, not veined; cortex (0-)10-40 $\mu \mathrm{m}$ thick; medulla 80-120 $\mu \mathrm{m}$ thick; stereome $50-80 \mu \mathrm{m}$ thick, poorly delimited from medulla, basal region always darkened, hyaline to yellowish in the upper regions; surface of central canal papillated; hymenial discs absent; conidiomata on the scyphal margins, brown, scarce, globose, slime hialyne; conidia slightly curved to falciform, 6-8 $\times 1 \mu \mathrm{m}$.

Chemistry: K-, C-, KC-, UV-. TLC: Fumarprotocetraric acid.

This species is distinguished by the whitish-grey podetia with a distinctly melanotic base, the podetial surface arachnoid and pruinose and by the scyphi deeply laciniate.

The specimens reach up to $10.0 \mathrm{~cm}$ tall and the scyphi form up to 11 tiers and thus are more developed than those reported by Gumboski \& Eliasaro (2012b) that described, for specimens from the rocky shores in Paraná State, podetia with $1.5-6.0 \mathrm{~cm}$ and 3-6 tiers. It is possible that the development of podetia could be influenced by altitude, as observed in $C$. imperialis (see under this species).
Cladonia flagellaris is similar to C. imperialis in having a strong melanotic base and podetial surface corticate, but the latter has greyish-green to brownish-green podetia, up to $31.0 \mathrm{~cm}$ tall, the scyphi form 8-17 tiers, the podetial surface is smooth, epruinose and distinctly venate. Furthermore, in C. imperialis the stereome is well delimited from medulla.

Cladonia crinita (Delise ex Persoon) Ahti also has the podetial surface arachnoid and scyphi deeply laciniate, but can be separated by the absence of a melanotic base and has a central canal with longitudinal cartilaginous ridges (Ahti \& Marcelli 1995, Ahti 2000) which are absent in C. flagellaris.

According to Ahti (2000), Cladonia flagellaris occurs on rock outcrops in semiopen habitats from sea level to 2,300 m of altitude. Gumboski \& Eliasaro (2012b) reported the species on Paraná State sea shore, in a partially shaded rocky shore, developing directly on rocks or on bryophytes. In the study area however C. flagellaris was found mainly growing directly on the soil and uncommonly on a thin layer of sediments on the rock, frequently isolated from other Cladonia species.

Distribution: Brazil, Minas Gerais (Ahti \& Marcelli 1995), Paraná (Ahti 2000), Rio de Janeiro and São Paulo States (Ahti \& Marcelli 1995). It is reported here for the first time for Santa Catarina State.

Specimens examined: BRAZIL. Santa Catarina: Garuva, Serra do Quiriri, Monte Crista, 26 $04^{\circ} 56^{\prime \prime} \mathrm{S}$ and 48 54'37"W, $970 \mathrm{~m}$ of altitude, 1-X-2009, F. Beilke s. n. (UPCB); 15-V-2010, E. Gumboski \& F. Beilke 1986, 1987, 1992 (UPCB). Joinville, Serra Dona Francisca, Castelo dos Bugres, 26 $6^{\circ} 13^{\prime} 41^{\prime \prime} \mathrm{S}$ and $49^{\circ} 03^{\prime} 33^{\prime \prime} \mathrm{W}$, $998 \mathrm{~m}$ of altitude, 7-I-2011, E. Gumboski \& F. Beilke 2216 (UPCB). Santo Amaro da Imperatriz, Pico da Serra do Tabuleiro, $27^{\circ} 49^{\prime} 00^{\prime \prime} \mathrm{S}$ and $48^{\circ} 53^{\prime} 07^{\prime \prime} \mathrm{W}$, 1,250 m of altitude, 13-VIII-2011, A.M. Charnei et al. 314, 370, 372, 399 (UPCB).

5. Cladonia imperialis Ahti \& Marcelli, Biblioth. Lichenol. 58: 19, 1995. Type: BRAZIL. Minas Gerais: Itamonte, Parque Nacional do Itatiaia, Agulhas Negras, 1993, Marcelli, Ahti \& Yano 28055 (holotype $\mathrm{S}$, isotype $\mathrm{B}, \mathrm{FH}, \mathrm{H}, \mathrm{NY}, \mathrm{RB}$ ).

Figure 6

Primary thallus not seen. Podetia 7.0-31.0 cm tall, 0.9-2.2 mm thick, greyish-green to brownish-green, strongly melanotic at base, frequently simple to rarely 
with up to three proliferations from scyphal center; podetial surface corticate, smooth, basal region cracked and upper regions areolate, soredia, granules and pruine absent; scyphi forming 8-17 tiers, with 0.6-3.0 cm wide, internodes $1.0-2.5 \mathrm{~cm}$; scyphal margins with squamules up to $0.8 \mathrm{~mm}$ long, mainly on young scyphi, always laciniate, laciniae dichotomously branched 2-4 times, usually recurved, flattened at the scyphal base, cylindrical and usually open near the apex, hollows, often erhizinate or with scarce rhizines with up to $1.1 \mathrm{~mm}$ long, black, at the lacinial apex of the older scyphi; upper side of scyphal plates corticate, perforated; lower side of scyphal plates ecorticate, whitish, veined, veins darkened in the older scyphi; cortex (0-)50-90 $\mu \mathrm{m}$ thick; medulla 200-300 $\mu \mathrm{m}$ thick; stereome 100-180 $\mu \mathrm{m}$ thick, well delimited from medulla, basal region always darkened, hyaline to yellowish in the upper regions; surface of central canal furrowed; hymenial discs absent; conidiomata frequent, on short pedicels at scyphal margins, light brown to dark brown, dolioliform to globose, slime hyaline; conidia falciform, 7-9 (-10) $\times 1 \mu \mathrm{m}$.

Chemistry: K-, C-, KC-, UV-. TLC: Fumarprotocetraric acid and traces of physodalic acid.

The podetia in Cladonia imperialis are very distinctive and tall, up to $31.0 \mathrm{~cm}$, and according Stocker-Wörgötter (2010) this species is probably the tallest known terricolous lichen wordwilde with a very high growth rate in the natural environment.

Although this species is easily identified, even in the field, due to their size, specimens with less developed podetia could be confused with Cladonia flagellaris (see under this species).

In the field was observed that the podetia are longer as altitude increases. The specimens occur only in high-altitude grasslands, from 1,600 m, and at this altitude they are infrequent and do not exceed $11 \mathrm{~cm}$ tall, while at $1,850 \mathrm{~m}$ they reach $31 \mathrm{~cm}$ and are more abundant. As the localities where they were found are very difficult to access and are rarely visited, it is unlikely that this difference is a result of anthropogenic disturbances. Stocker-Wörgötter (2010) studied the development of this species under culture conditions and found that stress by desiccation has a very positive effect on podetia morphogenesis, the tallest podetia are formed when the agar culture have completely dried. As the higher regions of Serra do Mar are fairly open and consequently receive more sunlight and occur more strong winds it is possible that these environmental conditions could be influencing the development of podetia.
Cladonia imperialis was found only in the two highest mountains of Paraná State, and in these sites, at altitudes above $1,800 \mathrm{~m}$, it is very abundant, forming extensive mats, growing alone or intermixed with other species of Cladonia as C. verticillaris, C. confusa $\mathrm{R}$. Sant. and C. crispatula (Nyl.) Ahti. Most specimens are terricolous but some were found on decaying vegetation and on thin layer of sediment on rocks.

Distribution: It was believed that this species was endemic to the Serra da Mantiqueira, with records only for Minas Gerais, Rio de Janeiro and São Paulo States in the Southeastern Brazil (Ahti \& Marcelli 1995, Ahti 2000). Here its distribution is extended to Southern Brazil, Paraná State.

Specimens examined: BRAZIL. ParanÁ: Campina Grande do Sul, Serra do Ibitiraquire, Morro Caratuva, $25^{\circ} 24^{\prime} \mathrm{S}$ and $48^{\circ} 49^{\prime} \mathrm{W}, 1,600 \mathrm{~m}$ of altitude, 14-VI-2009, V. Ariati 294 (UPCB); 1,700 m of altitude, 6-VII-2011, A.M. Charnei et al 167; 1,850 m of altitude, 6-VII-2011, A.M. Charnei et al.158, 160, 173, 179, 183, 199 (UPCB); Pico Paraná, $25^{\circ} 15^{\prime} \mathrm{S}$ and $48^{\circ} 48^{\prime} \mathrm{W}, 1650 \mathrm{~m}$ of altitude, 4-VII-2010, R. Rislows. n.(UPCB); 1,800 m of altitude, 6-VII-2011, A.M. Charnei et al. 211 (UPCB).

6. Cladonia penicillata (Vain.) Ahti \& Marcelli, Biblioth. Lichenol. 58: 19, 1995. Type: BRAZIL. Minas Gerais: Caraça, 1885, Vainio s.n. (lectotype designated by Ahti \& Marcelli 1995, TUR-V 18351).

Figure 7

Primary thallus not seen. Podetia (5.0-)7.0-12.0 cm tall, 1.2-2.0 mm thick, greyish-green to greyish-brown, not melanotic at base, but ocasionally brownish-yellow, frequently simple to rarely with up three proliferations from the scyphal center; podetial surface corticate, soredia, granules and pruine absent; scyphi forming 5-9(-11) tiers, with $1.0-2.3 \mathrm{~cm}$ wide, internodes 0.7-1.5 cm; scyphal margins with few squamules up to $0.7 \mathrm{~mm}$ long, laciniate, laciniae always branched 2-4 times, branched varying from dichotomy to polytomy, flattened at the scyphal base, cylindrical at the apex, hollows, with dense squarrose rhizinae with up to $3.0 \mathrm{~mm}$ long, black, mainly at the laciniae apex of basal scyphi; upper side of scyphal plates corticate, perforated; lower side of scyphal plates corticate, areolate, veined; cortex 20-30 $\mu$ m thick; medulla 140-200 $\mu \mathrm{m}$ thick; stereome 70-100 $\mu \mathrm{m}$ thick, well delimited from medulla, hyaline to yellowish; surface of central canal slightly furrowed; hymenial discs absent; conidiomata scarce, on the lacinial apex, brown, globose, slime hyaline; conidia falciform, $7-8(-9) \times 1 \mu \mathrm{m}$. 
Chemistry: K-, C-, KC-, UV-. TLC: Fumarprotocetraric acid.

The most diagnostic character of this species, as the species name indicates, is the production of tufts of black squarrose rhizinae along the scyphal margins (Ahti \& Marcelli 1995).

Cladonia imperialis and C. verticillaris also produce rhizines along the scyphal margins, but these are always sparse and inconspicuous, never as dense and long as in C. penicillata.

It was found growing isolated from other species of Cladonia, mainly on mosses or thin layer of sediment on rocks. The specimen A.M. Charnei et al. 221 was the only lignicolous found among all specimens of verticillate Cladonia throughout the study area.

Distribution: Cladonia penicillata is restricted to regions with high altitudes of Brazil (Ahti 2000). It is cited for Bahia (Ahti 2000), Espírito Santo, Goiás (Ahti \& Marcelli 1995), Minas Gerais States (Vainio 1894 as C. verticillaris var. flagellata Vain. and C. verticillaris var. penicillata Vain.), Paraná, Rio de Janeiro, Rio Grande do Sul and São Paulo States (Ahti \& Marcelli 1995). This is the first citation for Santa Catarina State.

Specimens examined: BRAZIL. PARANÁ: Campina Grande do Sul, Serra do Capivari, 1,600 m of altitude, 4-III-2007, P.B. Schwartsburd 1239 (UPCB); 1,200 m of altitude, 24-VIII-1989, V. Nicolack \& O.S. Ribas 35 (MBM); Serra do Ibitiraquire, Pico Paraná, $25^{\circ} 15^{\prime} \mathrm{S}$ and $48^{\circ} 48^{\prime} \mathrm{W}, 1,800 \mathrm{~m}$ of altitude, 6-VII-2011, A.M. Charnei et al. 221 (UPCB). Piraquara, Serra Marumbi, Morro do Bruninho, $25^{\circ} 23^{\prime} 03^{\prime \prime} \mathrm{S}$ and $49^{\circ} 00^{\prime} 16^{\prime \prime} \mathrm{W}, 1,230 \mathrm{~m}$ of altitude, 4-XI-2011, A.M. Charnei 466, 467, 468 (UPCB). Santa Catarina: Joinville, Serra Dona Francisca, Castelo dos Bugres, $26^{\circ} 13^{\prime} \mathrm{S}$ and $49^{\circ} 03^{\prime} \mathrm{W}, 998 \mathrm{~m}$ of altitude, 7-I-2011, E. Gumboski \& F. Beilke 2223, 2243 (UPCB). Santo Amaro da Imperatriz, Pico da Serra do Tabuleiro, $27^{\circ} 49^{\prime} \mathrm{S}$ and $48^{\circ} 53^{\prime} \mathrm{W}, 1,250 \mathrm{~m}$ of altitude, 13-VIII-2011, A.M. Charnei et al. 343, 349 (UPCB).

7. Cladonia rappii A. Evans, Trans. Connecticut Acad. Arts 38: 297, 1952. Type: UNITED STATES OFAMERICA.FLORIDA: SeminoleCo. Sanford, 1942, Rapps.n., Sandstede:Cladon. exs. 1938 p.p. (holotype US; isotype UPS).

Figure 8

Primary thallus generally evanescent to rarely persistent, consisting of lobed squamules, $1.0-2.3 \times 2.0-4.0 \mathrm{~mm}$, margins smooth, without rhizines, soredia and granules absent; upper surface green, corticate; lower surface white, ecorticate, not veined; cortex 50-90 $\mu \mathrm{m}$ thick; medulla 75-140 $\mu \mathrm{m}$ thick; conidiomata absent. Podetia (1.5-)3.0-10.0 cm tall, $0.7-2.3 \mathrm{~mm}$ thick, greenish-grey to brownish, usually melanotic at base, mainly simple to seldom with up to six proliferations from de scyphal center; podetial surface corticate areolate, often smooth to occasionally forrowed and broken, soredia, granules and pruine absent; scyphi forming (3-)5-12 tiers, with 2.1-7.0 mm wide, internodes $0.4-1.2 \mathrm{~cm}$; scyphal margins toothed, flat or recurved, erhizinate, sometimes with squamules up to $0.5 \mathrm{~mm}$ long; upper side of scyphal plates corticate, not perforated; lower side of scyphal plates corticate areolate, not veined; cortex 20-30 $\mu \mathrm{m}$ thick; medulla 200-220 $\mu \mathrm{m}$ thick; stereome 80-100 $\mu \mathrm{m}$ thick, well delimited from medulla, hyaline to yellowish; surface of central canal furrowed; hymenial discs 0.4-1.3 mm wide, frequents, brown to blackish-brown, usually on short pedicels at the scyphal margins; ascospores oblong, 10-12 × 3-4 $\mu \mathrm{m}$; conidiomata frequent, globose, dark brown, generally on the scyphal margins to infrequently on short pedicels, slime hyaline; conidia falciform, 7-8 $\times 1 \mu \mathrm{m}$.

Chemistry: K-, C-, KC-, UV-. TLC: Fumarprotocetraric acid.

Cladonia rappii can be easily distinguished from other species in the study area by the scyphi with upper side not perforated and margins toothed.

According Ahti (2000), the podetial surface of Cladonia rappii is minutely pruinose-arachnoid, especially in young parts, however this characteristic was not observed in any of the specimens studied. The same author reports that $C$. rappii is a very variable species which could contain more than one taxon, and the delimitations from C. cervicornis (Ach.) Flot. need closer analysis.

It closely resembles $C$. verticillata (Hoffm.) Schaer. (三C. cervicornis subsp. verticillata (Hoffm.) Ahti), a verticillate species not known in the Neotropics (Ahti \& Marcelli 1995), however this species, according to Brodo et al. (2001), has more gradually expanding scyphi that remain slightly concave, even when proliferating.

Although this is the first record of Cladonia rappi to Paraná State, this is the most common verticillate species and one of the most common Cladonia in Serra do Mar in Southern Brazil, occurring in almost 
all sites studied and also found among the unidentified specimens in herbaria, thus indicating how this group is poorly known in Southern Brazil.

It grows on mosses, thin layer of soil or sediment on rock, mostly isolated from other species of the genus, but it was also found intermixed with C. verticillaris, $C$. confusa and C. crispatula.

Distribution: According Fleig et al. (1995) this species has a wide distribution in tropical and temperate regions. Known in Oceania (Stenroos 1988), Asia (Wei 1991), Africa (Ahti 2000), North America (Evans 1952 apud Moore 1968), Central America (Ahti 2000) and South America (Lopez-Figueiras 1986) in Bolivia (Feuerer et al. 1998), Brazil (Fleig et al. 1995), Colombia, Ecuador, Peru (Ahti 2000) and Venezuela (Lopez-Figueiras 1986). In Brazil it is known on Minas Gerais , Rio de Janeiro (Ahti 2000), Rio Grande do Sul (Fleig et al. 1995) and Santa Catarina States (Ahti 2000). This is the first record for Paraná.

Specimens examined: BRAZIL. Paraná: Campina Grande do Sul, Serra do Capivari, Morro Capivari Grande, 30-IV-2000, Brock, F.L. s. n. (UPCB); 1,200 m of altitude, 24-VIII-1989, V. Nicolack \& O.S. Ribas 43 (MBM); Serra do Ibitiraquire, Morro do Getúlio, $25^{\circ} 14^{\prime} \mathrm{S}$ and $48^{\circ} 50^{\prime} \mathrm{W}, 1,230 \mathrm{~m}$ of altitude, 6-VII-2011, A.M. Charnei et al. 128, 134, 135, 149 (UPCB). Bocaiúva do Sul, Serra da Bocaina, 1,300 $\mathrm{m}$ of altitude, 6-I-2001, O.S. Ribas \& E. Barbosa 3184 (MBM). Morretes, Serra Marumbi, 1,100 m of altitude, 19-I-1995, O.S. Ribas et al. 786 (MBM). Quatro Barras, Serra da Baitaca, Morro Anhangava, $25^{\circ} 23^{\prime} \mathrm{S}$ and $49^{\circ} 00^{\prime} \mathrm{W}, 1,420 \mathrm{~m}$ of altitude, 14-VII-2011, A.M. Charnei et al. 245, 263 (UPCB). Piraquara, Serra Marumbi, Morro do Canal, 29-V-2002, S. Eliasaro 2255 (UPCB);

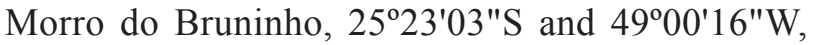
1,230 m of altitude, 4-XI-2011, A.M. Charnei 465 (UPCB). Guaratuba, Serra do Araçatuba, Morro dos Perdidos, $25^{\circ} 53^{\prime} \mathrm{S}$ and $48^{\circ} 57^{\prime} \mathrm{W}, 1,260 \mathrm{~m}$ of altitude, 31-VIII-2002, S. Eliasaro 2490 (UPCB); IV-2010, J. Rigon s. n. (UPCB); 15-IV-2011, A.M. Charnei et al. 18, 50, 53, 65 (UPCB). SANTA CatARINA: Garuva, Serra do Quiriri, $26^{\circ} 03^{\prime} \mathrm{S}$ and $48^{\circ} 56^{\prime} \mathrm{W}, 1,164 \mathrm{~m}$ of altitude, 7-V-2011, A.M. Charnei et al. 89, 91 (UPCB). Campo Alegre, Serra do Quiriri, 26 $00^{\prime} 52^{\prime \prime} \mathrm{S}$ and $49^{\circ} 00^{\prime} 39^{\prime \prime} \mathrm{W}$, $900 \mathrm{~m}$ of altitude, 26-XII-2011, E. Gumboski \& F. Beilke 3248, 3254, 3257 (UPCB). Joinville, Serra Queimada, 26 $07^{\prime} 14^{\prime \prime} \mathrm{S}$ and $49^{\circ} 02^{\prime} 46^{\prime \prime} \mathrm{W}, 1240 \mathrm{~m}$ of altitude, 4-IX-2011, A.M. Charnei \& F. Beilke 425 (UPCB). Santo Amaro da Imperatriz, Pico da Serra do
Tabuleiro, $27^{\circ} 49^{\prime} \mathrm{S}$ and $48^{\circ} 53^{\prime} \mathrm{W}, 1,250 \mathrm{~m}$ of altitude, 13-VIII-2011, A.M. Charnei et al. 382, 386 (UPCB).

8. Cladonia verticillaris (Raddi) Fr., Lichenogr. Eur. Reform. 465. 1831. Type: BRAZIL. Rio DE JANEIRO: Raddii s.n. (sintype FI-n.v).

Figure 9

Primary thallus not seen. Podetia 5.0-10.0(-20.0) $\mathrm{cm}$ tall, $0.7-2.0 \mathrm{~mm}$ thick, greyish-green to greyish-brown, not melanotic at base, however occasionally yellowish to brownish, frequently simple to seldom with up to four proliferations for the scyphal center; podetial surface corticate, broken at base, soredia, granules and pruine absent; scyphi forming 6-10 tiers, with (0.9-)1.1-2.0 cm wide, internodes $0.8-1.5 \mathrm{~cm}$, scyphal margins with abundantly squamules with up to $1.1 \mathrm{~cm}$ long, laciniate, laciniae dichotomously branched 2-4 times, flattened at the scyphal margins and cylindrical at the apex, hollows, recurved, usually with black rhizines at the laciniae apex with up to $1.0 \mathrm{~mm}$ long; upper side of scyphal plates corticate, perforated; lower side of scyphal plates whitish, often ecorticate to occasionally areolate, not veined; cortex 20-35 $\mu \mathrm{m}$ thick; medulla 140-150 $\mu \mathrm{m}$ thick; stereome 80-90 $\mu \mathrm{m}$ thick, well delimited from medulla, hyaline to yellowish; surface of central canal slightly furrowed; hymenial discs absent; conidiomata on the lacinial apex or on the scyphal margins, light brown to dark brown, globose to dolioliform, slime hyaline; conidia slightly curved to falciform, 7-8 $\times 1 \mu \mathrm{m}$.

Chemistry: K-, C-, KC-, UV-. TLC: Fumarprotocetraric acid and traces of physodalic acid.

Cladonia verticillaris is characterized by the whitish-green to greenish-brown podetia, the necrotic base yellow to brownish, scyphal upper surface perforated and margins with squamules (Ahti \& Marcelli 1995).

The most similar species are Cladonia calycanthoides and $C$. fissidens and the differences among these species have been presented when both were treated (see under these species).

It is common in the study area, found on decaying vegetation, soil and on thin layer sediments on rock, either alone or intermixed with other Cladoniaceae, as Cladia aggregata (Sw.) Nyl., Cladonia confusa and $C$. crispatula. In Morro Caratuva and Pico Paraná, it was often found developing together with C. imperialis.

Distribution: Cladonia verticillaris occurs from sea level to 1,500 m (Ahti 2000). Known only in South 


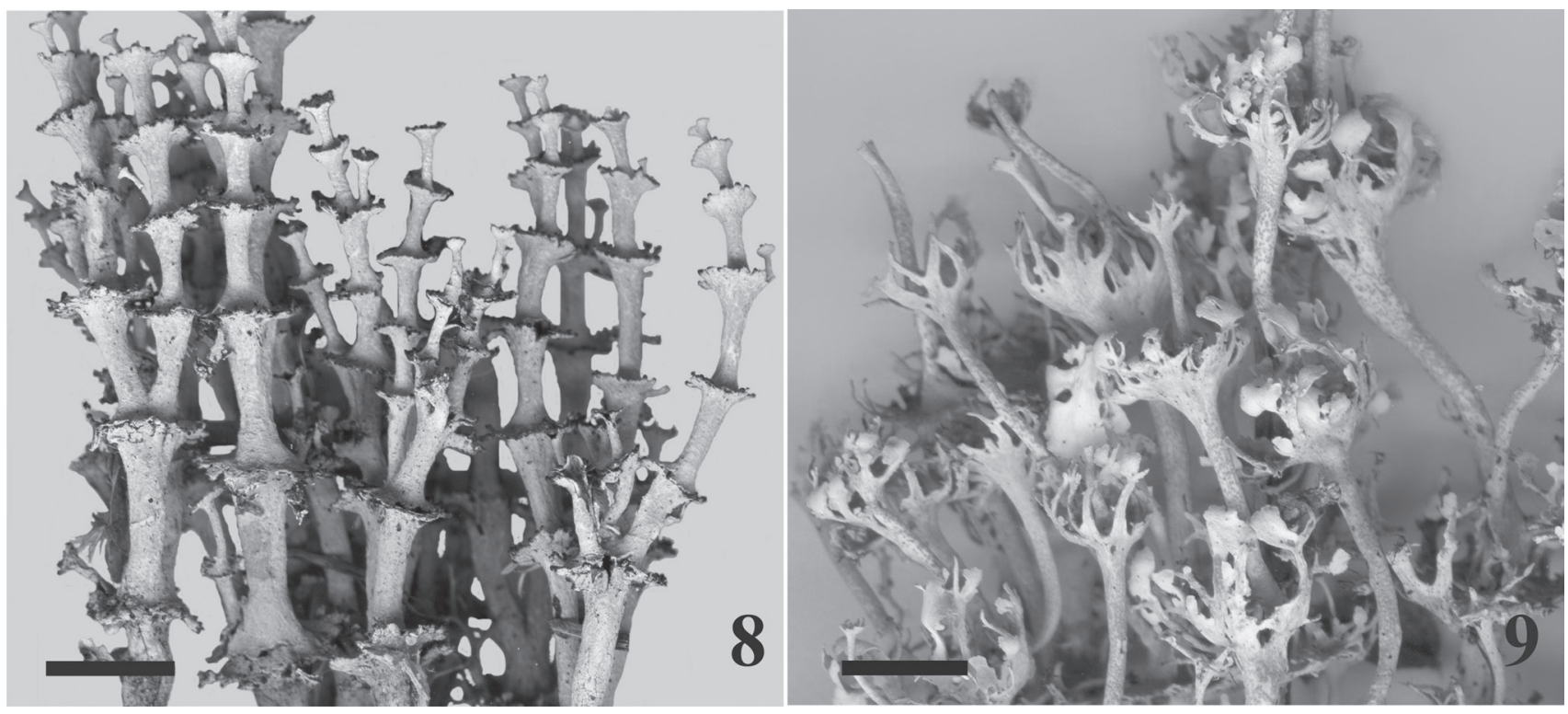

Figures 8-9: 8- Cladonia rappii (A. M. Charnei et al. 263). 9- C. verticillaris (A. M. Charnei et al. 390). Scale bars $=1 \mathrm{~cm}$.

America, in Brazil (Vainio 1894 - as C. verticillaris var. foliata (Meyer) Vain.) and Venezuela (Vareschi 1973). In Brazil it is known on Bahia, Espírito Santo, Goiás (Ahti 2000), Minas Gerais, Paraíba (Ahti et al. 1993), Pernambuco (Vainio 1984 - as C. verticillaris var. foliata Meyer), Paraná (Ahti \& Marcelli 1995), Rio de Janeiro (Vainio 1984 - as C. verticillaris var. foliata Meyer) and Rio Grande do Sul States (Fleig et al. 1995). This is the first citation for Santa Catarina State.

Specimens examined: BRAZIL. PARANÁ: Campina Grande do Sul, Serra do Ibitiraquire, Morro Caratuva, $25^{\circ} 24^{\prime} \mathrm{S}$ and $48^{\circ} 49^{\prime} \mathrm{W}, 1,850 \mathrm{~m}$ of altitude, 6-VII-2011, A.M. Charnei et al. 181 (UPCB). Morretes, Serra Marumbi, Pico Marumbi, 1,100 m of altitude, XII-1998, M. Borgo s.n. (UPCB). Piraquara, Serra Marumbi, Morro do Vigia, 28-III-2000, F.L. Brock 12 (UPCB). Guaratuba, Serra do Araçatuba, Morro dos Perdidos, 25 53'02"S and 48 $57^{\circ} 35^{\prime \prime} \mathrm{W}, 1,200 \mathrm{~m}$ of altitude, 4-XII-1998, E.P. Santos et al. 687 (UPCB); ibid, 1,300 m of altitude, 21-I-1994, R. Kummrov et al. 3402 (MBM). SANTA CATARINA: Garuva, Serra do Quiriri, Monte Crista, 26 $04^{\circ} 56^{\prime \prime S}$ and 48 54' $^{\circ} 7^{\prime \prime} \mathrm{W}$, $970 \mathrm{~m}$ of altitude, 15-V-2010, E. Gumboski \& F. Beilke 1956, 1973 (UPCB). Campo Alegre, Serra do Quiriri, $26^{\circ} 01^{\prime} 35^{\prime \prime} \mathrm{S}$ and $48^{\circ} 58^{\prime} 57^{\prime \prime} \mathrm{W}, 1,300 \mathrm{~m}$ of altitude, 3-II-2012, E. Gumboski et al. 3276 (UPCB). Joinville, Serra Dona Francisca, Castelo dos Bugres, $26^{\circ} 13^{\prime} 41^{\prime \prime} \mathrm{S}$ and $49^{\circ} 03^{\prime} 33^{\prime \prime} \mathrm{W}, 998 \mathrm{~m}$ of altitude, 7-I-2011, E. Gumboski \& F. Beilke 2227, 2235, 2240, 2241,
2256, 2264 (UPCB); 12-VIII-2011, A.M. Charnei et al. 417 (UPCB). Santo Amaro da Imperatriz, Pico da Serra do Tabuleiro, $27^{\circ} 49^{\prime} \mathrm{S}$ and $48^{\circ} 53^{\prime} \mathrm{W}, 1,250 \mathrm{~m}$ of altitude, 13-VIII-2011, A.M. Charnei et al. 331, 342, 366, 373, 375, 390, 402 (UPCB).

\section{Acknowledgements}

We are grateful to Alice Gerlach, Emerson Gumboski, Flávio Beilke, Vanessa Ariati and Victor Batista for their assistance in the field. Very special grateful thanks to Emerson Gumboski for his support and enthusiasm. We thank the curator of MBM for the loan of specimens. We also thank FATMA (Fundação do Meio Ambiente) and IAP (Instituto Ambiental do Paraná) for the permission to collect, and CAPES (Coordenadoria de Aperfeiçoamento de Pessoal de Nível Superior) for granting a Mastership to Charnei.

\section{References}

Ahti, T. 2000. Cladoniaceae. Flora Neotropica 78. Organization for Flora Neotropica and New York Botanical Garden, New York.

Ahti, T. \& Marcelli, M.P. 1995. Taxonomy of the Cladonia verticillaris complex in South America. In: E. E. Farkas, R. Lücking \& V. Wirth (Eds.). Scripta Lichenologica - Lichenological Papers Dedicated to Antonín Vezda. Bibliotheca Lichenologica 58: 5-26.

Ahti, T., Stenroos, S. \& Xavier Filho, L. 1993. The lichen family Cladoniaceae in Paraiba, Pernambuco and Sergipe, Northeast Brazil. Tropical Bryology 7: 55-70. 
Almeida, F.F.M. \& Carneiro, C.D. 1998. Origem e Evolução da Serra do Mar. Revista Brasileira de Geociências 28: 135-150.

Blum, C.T., Roderjan, C.V. \& Galvão, F. 2011. O clima e sua influência na distribuição da Floresta Ombrófila Densa na Serra da Prata, Morretes, Paraná. Floresta 41: 589-598.

Brodo, I.M., Sharnoff, S.D. \& Sharnoff, S. 2001. Lichens of North America. Yale University Press, New Haven, London.

Culberson, C.F. \& Ammann, K. 1979. Standard method zur Dünnschicht chomatographie von Flechtensubstanzen. Herzogia 5: 1-24.

Elix, J.A. \& Ernst-Russell, K.D. 1993. A Catalogue of Standardized Thin Layer Chromatographic Data and Biosynthetic Relationships for Lichen Substances. 2 ed. Australian National University, Camberra.

Evans, A.W. 1952. The Cladoniae of Florida. Transactions of the Connecticut Academy of Arts and Sciences 38: 249-336.

Feuerer, T., Ahti, T. \& Vitikainen, O. 1998. Lichenological investigations in Bolivia. In: M.P. Marcelli \& M.R.D. Seaward (eds.): Lichenology in Latin America: History, current knowledge and applications. CETESB, São Paulo, pp.71-86.

Fleig, M., Ahti, T. \& Stenroos, S. 1995. A família Cladoniaceae (liquens) no Rio Grande do Sul, Brasil. Napaea 11: 1-29.

Gumboski, E.L. \& Eliasaro, S. 2011a. Cladonia litoralis (Cladoniaceae), a new species from southern Brazil. The Bryologist 114: 665-667.

Gumboski, E.L. \& Eliasaro, S. 2011b. Checklist of lichenized fungi of Santa Catarina State (Brazil). Mycotaxon 115: 535.

Gumboski, E.L. \& Eliasaro, S. 2012a. Espécies de Cladonia P. Browne (Cladoniaceae, Ascomycota) dos Supergrupos Cocciferae, Crustaceae e Perviae em restingas e costões rochosos dos Estados do Paraná e de Santa Catarina, Brasil. Acta Botanica Brasilica 26: 619-631.
Gumboski, E.L. \& Eliasaro, S. 2012b. Espécies de Cladonia P. Browne (Cladoniaceae, Ascomycota) do Supergrupo Cladonia em restingas e costões rochosos dos Estados do Paraná e de Santa Catarina, Brasil. Hoehnea 39: 315-337.

IAPAR. Instituto Agronômico do Paraná. 2012. Cartas climáticas do Paraná. http://www.iapar.br/ modules/ conteudo/conteudo.php? conteudo $=863$ (access in 21.08.2012).

IBGE. Instituto Brasileiro de Geografia e Estatística. 1992. Manual Técnico da Vegetação Brasileira (Manuais Técnicos de Geociências, $n^{\circ}$ 1). Fundação Instituto Brasileiro de Geografia e Estatística, Departamento. de Recursos Naturais e Estudos Ambientais, Rio de Janeiro.

Lopez-Figueiras, M. 1986. Censo de macroliquens Venezolanos de los Estados Falcon, Lara, Merida, Tachira y Trujillo. Universidad de los Andes, Mérida.

Moore, B.J. 1968. The Macroliquen Flora of Florida. The Bryologist 71: 161-266.

Santos, A.R. 2004. A grande barreira da Serra do Mar: da trilha dos Tupiniquins à Rodovia dos Imigrantes. $\mathrm{O}$ Nome da Rosa, São Paulo.

Stenroos, S. 1988. The family Cladoniaceae in Melanesia. 3. Cladonia sections Helopodium, Perviae and Cladonia. Annales Botanici Fennici 25: 117-148.

Stocker-Wörgötter, E. 2010. Stress and Developmental Strategies in Lichens. In: J. Seckbach \& M. Grube (eds.). Symbioses and Stress - Joint Ventures in Biology, Series: Cellular Origin, Life in Extreme Habitats and Astrobiology, v.17, pp. 525-546.

Taylor, C.J. 1967. The lichens of Ohio. Part I. Foliose lichens. The Ohio Biological Survey. The Ohio State University Press, Columbia.

Taylor, C.J. 1968. The lichens of Ohio. Part II. Fruticose lichens. The Ohio Biological Survey. The Ohio State University Press, Columbia.

Vainio, E.A. 1894. Monographia Cladoniarum universalis. II. Acta Societatis Pro Flora et Fauna Fennica 10: 1-498.

Vareschi, V. 1973: Resultados liquenológicos de excursiones efectuadas en Venezuela. No. 3. Catalogo de los líquenes de Venezuela. Acta Botanica Venezuelica 8: 177-245.

Wei, J.C. 1991. Cladina and Cladonia. An enumeration of lichens in China. International Academic Publishers, Beijing. 
